\author{
MARYNA DIELINI, \\ National University of Life and Environmental Sciences of Ukraine (Kyiv, Ukraine) \\ e-mail: marina.dielini@gmail.com,ORCID 0000-0003-1016-2305
}

\title{
EVOLUTION OF BUSINESS ETHICS: FROM GENERAL PHILOSOPHICAL PRINCIPLES TO CORPORATE SOCIAL RESPONSIBILITY
}

The article traces the evolution of business ethics from the ideas of simple human responsibility that were put forward by ancient thinkers to complex philosophical moral and ethical, socio-economic constructions on corporate social responsibility. It is noted that in the process of such evolution a whole system of views, judgments and constructions was formed, which should be considered as peculiar stages of further theoretical understanding and expansion of the thematic framework of the phenomenon of "corporate social responsibility". The analysis showed that the issues of business ethics and social responsibility (and corporate social responsibility as its highest manifestation) have always been most raised in the so-called turning points in the worldview paradigm of human civilization, and the most important theoretical achievements are related to the rationalization of social relations, when the acquired moral and spiritual values were included in the growth of socio-economic resources of society. It is shown that in the 21st century there is a steady demand from business to study the issue of social responsibility, which allows social technologists - representatives of various scientific fields to expand the categorical apparatus, filling new concepts of business ethics, as well as initiate new scientific discussions - valuable principles of society and various pragmatic concepts, the components of which are "principles-process-results".

Key word: responsibility; social responsibility of business, ethics, morality, personal responsibility.

\section{Introduction}

In today's society, social responsibility of entrepreneurship plays an important role as a chain that combines social norms and business. This issue becomes the object of study of various sciences, namely: economics, philosophy, sociology, law. In general, we can add that CSR can be in any area where there is a business component.

One of the main followers and founder of corporate social responsibility is A. Carroll, who defines it as "Corporate social responsibility encompasses the economic, legal, ethical, and discretionary (philanthropic) expectations that society has of organizations at a given point in time" (Carroll, 2016). At present, CSR is gaining significant development and acquiring In today's society, social responsibility of entrepreneurship or corporate social responsibility (CSR) plays an important role as a chain that combines social norms and business. This issue becomes the object of study of various sciences, namely: economics, philosophy, sociology, law. In general, we can add that CSR can be in any area where there is a business component.

One of the main followers and founder of corporate social responsibility is A. Carroll, who defines it as "Corporate social responsibility encompasses the economic, legal, ethical, and discretionary (philanthropic) expectations that society has of organizations new forms of manifestation, more and more companies are turning to it as a means to improve their image and to increase the share of market position. CSR has positive consequences not only for the company's stakeholders, but also for the company itself, its profits and maintaining a competitive position.

But the foundations of CSR were laid long before that and we can turn to the history of the philosophical vision of this phenomenon. The first explanations of the phenomenon of responsibility are contained in the works of ancient philosophers, who were the first to raise the question of human responsibility for their actions. The works of Western European philosophers of the XVII - XVIII centuries T. Hobbes, J. Locke, M. Montaigne, D. Hume, A. Schopenhauer complicated the dogma of responsibility with ideas about the relationship of freedom and necessity, personality and society, responsibility as a natural state of personality and society. Religious and spiritual teachings pay considerable attention to the issue of human responsibility, and scientific concepts of the 19th and 20th centuries focus on explaining the nature of such responsibility. What are the components and characteristics of responsibility brought to life and led to the formation of such a phenomenon as corporate social responsibility and is the subject of our article.

\section{Methodology}

In the article it is used such methods as analysis and synthesis - to describe the philosophical aspect of corporate social responsibility. As well as theoretical methods, namely: generalization and historical method, which involves the establishment of general relations between categories, their historical study and study of origin and development as a basis for the current state of affairs. 
Methods of analysis, synthesis, extrapolation and generalization are also used to make conclusions, judgements.

\section{Results and Discussion}

If we turn to the modern definitions of the categories "responsibility", "social responsibility", and the theoretical foundations of measuring socially responsible behavior of the subject, we can talk about their narrow and broad interpretation. "Narrow" understanding of responsibility is based on a set of certain characteristics, actions, qualities of people with responsible behavior. In such definitions (they are given, for example, in the works of Titarenko, 2008; Ruchkina, 2008; Yermolenko, 1994) responsibility appears as a consequence, the ability to predict the results of their actions, as well as a certain quality of personality to voluntarily agree and creatively direct their actions for progress. humanity (see for example, Shybko, 2012; Platonova, 2013; Silveira, Muzzio, Costa, 2015). A broad interpretation of responsibility is based on its definition as a phenomenon of human existence, which reflects the objective historically specific nature of the relationship between the individual, team, society in terms of con- scious satisfaction of mutual requirements for them (Philosophical Dictionary, 1983: 469). In other words, this understanding, in our opinion, strengthens the link "responsibility - social responsibility". Because this understanding is based on the interaction of individual and organized human energies, which together form the concept of the subject of social activity. A. Kolot argues that the subject of social activity is both a subject of social responsibility, referring to such subjects and the individual, and various social groups, collectives, organizations, states, peoples, humanity as a whole (Kolot at all, 2015). Social responsibility, as follows from the above, is not abstract, impersonal. At the same time, this phenomenon presupposes the obligatory existence of the object of socially responsible behavior, ie for which the subject of activity is responsible, which is assigned to him or accepted by him as an obligation, the norm of activity.

Table 1 through the opinion of the most famous thinkers of different eras presents the development of human ideas about responsibility and communicative capabilities of society.

Table 1. Views of philosophers on responsibility

\begin{tabular}{|c|c|c|}
\hline Scientist & Historical period & Main idea \\
\hline Plato & IV st. B.C. & $\begin{array}{l}\text { The clearly formed question is to what extent a person is consciously and vol- } \\
\text { untarily the creator of his actions and to what extent he or she is responsible for } \\
\text { them. Plato recognized for man the possibility of free choice and thus respon- } \\
\text { sibility for their actions. In addition, he saw the roots of responsibility, which lie } \\
\text { in the relationship between people, which is imposed on a particular person, } \\
\text { the defining responsibilities, the performance of which characterizes his re- } \\
\text { sponsibility. }\end{array}$ \\
\hline Aristotle & IV st. B.C. & $\begin{array}{l}\text { In Nicomachean Ethics, he described ethics and politics as the science of the } \\
\text { free choice that a person responsible for his actions makes. Connects the con- } \\
\text { cept of responsibility with freedom of will and freedom of choice. He rightly } \\
\text { raises the question of the possibility and appropriateness of a person's respon- } \\
\text { sibility for actions he commits due to ignorance of certain rules and norms. }\end{array}$ \\
\hline Democritus & V-IV centuries. B.C. & $\begin{array}{l}\text { A person must evaluate his actions not only from the point of view of others, } \\
\text { but also from the standpoint of his own moral attitude to them. }\end{array}$ \\
\hline T. Hobbes & XVII century & $\begin{array}{l}\text { Connects the fact of the emergence of the category of responsibility with the } \\
\text { emergence of the state, society as a whole. He argues that public (social) re- } \\
\text { sponsibility arises as a result of the transfer of people's rights to public power. } \\
\text { The responsibility of the individual arises as a result of the powers of public } \\
\text { authority. }\end{array}$ \\
\hline J. Locke & XVII century & $\begin{array}{l}\text { In his views on responsibility, the starting point is the natural state of society. } \\
\text { This is "a state of freedom, however, not a state of chaos. Although a person in } \\
\text { this state has a freedom that is not controlled by anything. She can do anything } \\
\text { with herself and her property, but she does not have the freedom to destroy } \\
\text { herself or any creature. " A person's freedom is restricted by a natural law (i.e., } \\
\text { responsibility), which states that "no one has the right to restrict another in his } \\
\text { life, health, liberty, or property." }\end{array}$ \\
\hline P. Holbach & XVIII century & $\begin{array}{l}\text { For the first time he expressed the opinion about the responsibility of socie- } \\
\text { ty to man, because society itself can shape certain human traits (create bad } \\
\text { people). }\end{array}$ \\
\hline I. Kant & XVIII century & $\begin{array}{l}\text { He considered responsibility from the standpoint of "pure reason" and recog- } \\
\text { nized the true instance of responsibility is not the state, but the basis of abso- } \\
\text { lute moral law. This absolute moral law is embodied in the human conscience. } \\
\text { Kant's conscience is a subjective principle of responsibility, and its objective } \\
\text { side is a categorical imperative - a system of social values as an objective ab- } \\
\text { solute moral law. }\end{array}$ \\
\hline K. Marx & XIX century & $\begin{array}{l}\text { Analyzes responsibility as a historically determined phenomenon, taking into } \\
\text { account the class-specific historical approach of human activity in organic con- } \\
\text { nection with the needs of society. }\end{array}$ \\
\hline
\end{tabular}


Table 1. Continued

\begin{tabular}{|c|l|l|}
\hline E. Fromm & XX century & $\begin{array}{l}\text { Characterizes responsibility as a harmony between opposite human character- } \\
\text { istics. He points out that responsibility is a person's ability to reach a certain } \\
\text { consensus between the freedom he or she desires as an individual and the } \\
\text { responsibilities he or she accepts as a member of society. }\end{array}$ \\
\hline K.-O. Apel & XX century & $\begin{array}{l}\text { joint responsibility for solving problems and equality in solving problems of all } \\
\text { members of the real communicative community; a real solution to problems - } \\
\text { even those that are ethically relative - must be consensually capable for all } \\
\text { members of the unlimited ideal communicative community, as if they are direct- } \\
\text { ly discussing it with each other; responsibility for the needs of future people. }\end{array}$ \\
\hline H. Jonas & XX century & $\begin{array}{l}\text { The ethics of responsibility includes two responsibilities in relation to } \\
\text { the future: the first duty is to develop and generate ideas about the possible } \\
\text { long-term consequences of collective practice; and the associated duty - "cour- } \\
\text { age to fear" - refraining from actions whose consequences may threaten the } \\
\text { future existence of humanity. }\end{array}$ \\
\hline
\end{tabular}

* Table formed on the bases of (Ivanova, 2012; Apel, 1999; Jonas, 2001; Hajikurbanova, 2003).

This table shows that until the second half of the 20th century philosophers generally consider responsibility as a person's responsibility for his/her actions to himself and society. They considered, taking into account that a person is free in his/her choice, he/she is responsible for his/her behavior. But in our world, each person coexists with others, that is, he/she is a social being and acts in a certain socio-cultural aspect. This is what imposes certain obligations on his/her and sets the limits of his/her actions and activities. In addition, the ecological and energy crisis, technological and economic expansion, staggering advances in biology and medicine have put human existence at stake. Understanding the causes, meaning and possible consequences of global crises led to the fact that the apologists of philosophical thought shifted the understanding of responsibility from the individual to the collective level and tried to formulate its adequate provisions capable of interacting with technological rationality.

This understanding of responsibility is reinforced by ideas about the loss of the stability of social systems, about the loss of the foundations of life and the connection between generations in the life of an individual. This global problem of change in the content of interpersonal relations, disparities in social development, changes in the structure of values of members of society draws attention, for example, E. Giddens in his work "Consequences of modernity." For modern society, he writes, is characterized by increasing disorientation of people, the source of which is the gap of succession in the development of society, as well as social and cultural traditions (Giddens, 1990: 132). Systematic overcoming of such a scale of crisis is possible under the condition of creating a system of relationships that will be able to produce actions and behavior of subjects in accordance with socially significant values, principles, norms that meet the interests, ideals and objectives of society and personal development. That is, we approach the concept of "social responsibility", which is multifaceted in terms of its subjectivity, direction and contextuality.

According to the topic of our study, we associate social responsibility with CSR and conclude that business responsibility begins with the moral values of business leaders. If a person treats the environment responsibly, understands his own responsibility for actions within a certain community, in relation to staff, etc., then it is formed in responsible way. Social responsibility of business is directed to society and to everyone.

At this stage, social responsibility is faced with the development and deepening of its manifestations. Its implementation can include the development of the personality of each employee, the development of social programs, solving urgent environmental problems and others. Here is taken place the intersection of sciences in which social responsibility can be considered and studied. Since, in addition to the legislative regulator, CSR can also be based on the own views of the owner of the enterprise and its managers, which are formed taking into account many factors: upbringing, education, experience of other entrepreneurs, the norm in society.

To conduct scientific research, we will first identify forms of social responsibility of business, as well as groups of stakeholders. Forms of CSR are decent level of wages, compliance with legislation, staff development, fair business, timely payment of taxes, compliance with legal agreements with suppliers and partners, fair competition, manufacturing quality products, taking into account the needs of consumers in the production of goods or services and more. Among stakeholders can be identified the following groups: company staff, owners, competitors, partners, consumers, the state (as a tax recipient), society as a whole.

One of the modern philosophers - A.A. Kravchenko also distinguishes between external and internal responsibility. She views the external as social responsibility, and the internal as personal responsibility (Kravchenko, 2013). That is, the usual understanding of CSR can be considered by this author as a manifestation of external responsibility. In the development of this view, it can be argued that these two types of responsibility are not independent of each other, but, on the contrary, complement each other and the external is a consequence of internal responsibility. That is, it confirms the opinion of previously considered scientists.

Morality and value qualities of people not only form their own external responsibility, but are also decisive for the emergence of all types and manifestations of human responsibility. Human qualities are manifested at any stage and level of human activity, such as business, relationships with partners, competitors, consumer orientation. 
A.I. Andryushchenko and I.M. Ryabets argue that the responsibility of the individual is formed in response to the demands placed on him/her by society, social group or community in general. They are the motivators of his behavior, which lead to a certain degree of responsibility. Scholars also note that social responsibility is interpreted as a combination of its various types - economic, political, legal, moral, and so on (Andryushchenko, Ryabets, 2009). However, they all combine the responsibility of the individual to society. This is the sociological meaning of social responsibility, when a person is ready to realize mutual rights and responsibilities in the process of joint activities in order not to harm the sustainable development of society as a whole and individual communities, individuals. This expresses the social responsibility of the individual, when a person prefers the interests of the population, even if they do not coincide with the personal interests of the individual (Dielini, 2014).

Some scientists have also seen attitudes toward Confucianism. Koehn D. notes that in addition to him, Romar, Lam, Chan, Woods and Lamond believe that Confucianism may have some information about the ethics of virtue, which is one of the foundations of CSR (Koehn, 2020).

Ethical and moral qualities of a person thus become decisive for the social responsibility of both the individual and the business. If it has certain views on its duty to groups of stakeholders, then they are manifested in the social responsibility of business.

O. Shybko in his study notes that the whole history of humanity is a history of development and change of forms of social responsibility. He identifies 5 of its forms, namely:

1. Collective responsibility - primitive society, when responsibility was primitive in nature and was a consequence of the need for self-preservation. This form of responsibility gives rise to social groups of people, such as family, clan, etc.

2. Ethnic-class responsibility - pre-industrial societies, when there is a development of private property and the state, as well as the division of labor.

3. National-class responsibility - inherent in industrial societies. The creation of a capitalist system contributed to the spread of responsible ties.

4. National responsibility - post-industrial society. This responsibility is already created to preserve the integrity of the social system and acquires a universal nature of mutual responsibility for the development of society and each individual.

5. Universal responsibility - is the responsibility for the fate of civilization in terms of its further development (Shybko, 2012).

This author also formulated the law of growth of social responsibility, which consists in the transition from the historical need to freely choose the best behavior and activities in the interests of progressive development of society in need for each subject of social relations (Shybko, 2012).

This approach deserves attention given that social responsibility looks like a necessity that was formed in humanity in the beginning for survival, and then took the form and responsibility of business, which began to develop with the development of economic and labor relations. That is, in this we see CSR as a response to human development.

Busakorn Watthanabut in his study of social responsibility and morality in Kant's work, notes that the motivating factor for responsible behavior is important. It is a matter of motivation and duty, which is to respect the moral law. That is, in this case, social responsibility is not only a moral aspect, but there is a concept of responsibility as an informal law. Our motivation here is respect for this law, which becomes our duty. That is, if the manager believes that social responsibility is his responsibility, he will abide by it in any case. Thus, based on this philosophical point of view, we can assume that it is possible to cultivate from childhood social responsibility as a moral law, which must be observed as a code of conduct (Busakorn Watthanabut, 2017).

A group of scientists Silveira R.A., Muzzio H., Costa F.J. studied the social responsibility of business in combination with ethics. They ask the following questions: "Why should a businessman not mislead his consumer?", "Why should he be ethical?" etc. It is difficult to distinguish ethics and CSR both separately from each other and separately from the economy. Under capitalism, they acquire special significance (Silveira et al., 2017). This can be explained by the fact that under capitalism, in times of free competition, entrepreneurs can deviate from their moral foundations in favor of profits. That is in order to maximize their cash flow, they may violate morals and ethics. One could agree with this a few decades ago, but at this time in developed countries, on the contrary, there is a development of the moral component of entrepreneurship. CSR becomes a means of improving the company's image and is used as a tool for this.

Also, these scientists propose the introduction of 4 categories in the theory of corporate social responsibility, namely: the ethical personality of the organization, the ethical community, freedom and identity between ethics and interest. They point out that interest can be sacrificed in the name of social responsibility. If you choose interest, then you will not be socially responsible (Silveira et al., 2017). The main thing in this is the combination and reaching a compromise between the interest of the entrepreneur and ethical behavior.

Hejjas K., Miller G., Scarles C. note that not only entrepreneurs but also their employees and subordinates should be involved in CSR. They act here as a group of stakeholders, but also as performers (Hejjas et al., 2019). Involvement of employees is also a consequence of their own morale and attitude to CSR.

If we turn again to A. Carroll and his pyramid of CSR, which distinguishes its 4th level, then there you can find ethical responsibility, along with economic, legal and philanthropic. That is, he singled it out as a separate responsibility within the entire CSR. Can ethics and social responsibility be considered identical?

The main question is: "Why should a person or businessman be socially responsible?" To do this, it is necessary to answer the following question: "Does a socially responsible business start with a responsible person?" "What is decisive for corporate social responsibility?"

In our opinion, the answer to this question depends on the level of development of the country and society. Countries that are just beginning to develop are less socially responsible, based on this we can say that the moral qualities of their businessmen are lower than in developed countries. They give way to ethical concessions in agreement of their interests - to increase profits. While in developed countries, business leaders already combine their interest with ethics and are more socially responsible. It is difficult to single out what is paramount - ethics, which has become the basis for the development of social responsibility or understanding the need to be responsible, because it is a modern trend that has a positive impact on attitudes towards the company. 
Based on this, we can identify two factors of socially responsible business: 1. Moral qualities of managers, their vision of responsibility as a norm of behavior; 2 . Understanding the need for this process, taking into account the demands of society at this time. Such demands of society are also a manifestation of morality, which allows us to conclude that these two factors are interconnected and influence each other. The development of the 2nd factor can lead to the same result as the first: when it is a moral duty, then social responsibility is the norm, a person-entrepreneur who considers CSR as his ethical duty, rule of conduct, that goes without saying. Similarly, when society demands it and the entrepreneur acts from it, over time it will become what will be perceived as the norm of behavior of any enterprise. In this case, CSR will become a norm of behavior, a morality that will be normal for every entrepreneur. In this case, we get influence on the formation of norms of behavior in response to the request of society, the legal requirement (compliance with laws, codes). Although CSR is voluntary in nature, and this is its basic principle, it is already the first country to make social responsibility mandatory: India has obliged companies that have reached a certain level of profitability to do charity. That is, not only voluntariness, but also coercion in the implementation of CSR is already beginning to operate here.

In the development of the above we can talk about the implementation of the philosophical law of the mutual transition of quantitative changes in quality, when CSR with its constant repetition becomes the embodiment of qualitative changes, namely, becomes the norm of behavior.

Morsing M., Spence L. J. in their study note that small businesses do not believe that they are engaged in social responsibility, but the analysis of their activities shows that they actually carry out CSR (Morsing et al., 2019). It can also be considered a manifestation of the morality of these enterprises, which does not mean the lack of morality of large enterprises, it only means that small and medium enterprises are less focused on attracting attention and shaping their image through CSR.

Scientists point to social responsibility as the latest requirement for the modern existence of enterprises (Breus et al., 2020; Brieger et al., 2020; Malik, 2020) and its acute importance for today's entrepreneurship as a means of improving their environment.

\section{Conclusion}

Thus, in the process of evolution of business ethics from the ideas of simple human responsibility put forward by ancient thinkers to complex philosophical moral and ethical, socio-economic constructions concerning corporate social responsibility the whole system of views, judgments and constructions which should be considered as original stages of further theoretical comprehension and expanding the thematic framework of the phenomenon of "corporate social responsibility".

Our analysis shows that the issues of business ethics and social responsibility (and corporate social responsibility as its highest manifestation) have always been most raised in the so-called turning points in the worldview paradigm of human civilization, and the most important theoretical achievements are related to the rationalization of social relations, when the acquired moral and spiritual values were included in the growth of socio-economic resources of society. We have identified two factors in the development of social responsibility today, which are the result of two processes: strengthening the morality of a developed society and asking business leaders about their social responsibility, which is also a consequence of raising the morale of the population.

Human development requires to be socially responsible, which can also affect the responsibility of business. If at first social responsibility was a requirement of survival, then over time and the development of economic relations, it became necessary for enterprises. In addition to the entrepreneurs themselves, their employees can also be involved in CSR, which can also be not only a response to management's instructions, but also the employee's own moral values. Therefore, the determining factor is the moral basis for the implementation of CSR, its perception as a norm of existence.

\section{REFERENCES}

Andryushchenko, A.I., Ryabets, I.M. (2009). Sotsialna vidpovidalnist: teoretyko-metodolohichnyy aspekt analizu. Visnyk Kharkivskoho natsionalnoho universytetu im. V.N. Karazina, 844 (23): $133-135$.

Apel, K.-O. (1999). Dyskursyvna etyka yak politychna etyka vidpovidalnosti u sytuatsiyi suchasnoho svitu (translat. from Germ. by A.Yermolenko). In: A.Yermolenko Komunikatyvna praktychna filosofiya. Kyiv : Libra, 395-412 (In Ukrainian).

Breus, S., Solokha, D., Bieliakova, O., Derii, Z. \& Dielini, M. (2020). Entrepreneurship development model under conditions of business social responsibility. Academy of Entrepreneurship Journal, 26 (3): 1-8. Retrieved from https://www.abacademies.org/articles/Entrepreneurship-developmentmodel-under-conditions-of-business-social-responsibility1528-2686-26-3-364.pdf.

Brieger, S.A., Anderer, S., Fröhlich, A. et al. (2020). Too Much of a Good Thing? On the Relationship Between CSR and Employee Work Addiction. J Bus Ethics, 166: 311-329. DOI: https://doi.org/10.1007/s10551-019-04141-8.

Busakorn Watthanabut (2017, July-December). The Corporate Social Responsibility according to Kant Moral's Philosophy. Asian Political Science Review, 1 (2): 13-18.

Carroll, A.B. (2016)/ Carroll's pyramid of CSR: taking another look. Corporate Soc Responsibility, 1, 3 DOI: https://doi.org/10.1186/s40991-016-0004-6

Dielini, M.M. (2014). Multyvymirnyy aspect vidpovidalnosti pidpryyemnytstva ta yiyi rol $\mathrm{v}$ rozvytku natsionalnoyi ekonomiky. Efektyvna ekonomika, 12. URL : http://www.economy.nayka.com.ua/?op=1\&z=6147 (In Ukrainian)

Filosofskiy entsiklopedicheskiy slovar (1983). Ovetstvennost. Moscow: Sovetskaya entsiklopediya: 469. (In Russian)

Gadzhikurbanova, P. A. (2003). Strakh i otvetstvennost: etika tekhnologicheskoy tsivilizatsii Gansa Yonasa. Eticheskaya mysl, 4: 161-178 (In Russian).

Giddens, Anthony (1990). The Consequences of Modemity. Cambridge: Polity Press.

Ivanova, O. I. (2012). Yurydychna vidpovidalnist yak riznovyd sotsialnoyi vidpovidalnosti [Legal liability as a kind of social responsibility]. Visnyk Akademiyi advokatury Ukrayiny. Chyslo 3 (In Ukrainian)

Jonas, G. (2001). Pryntsyp vidpovidalnosti. U poshukakh etyky dlya tekhnolohichnoyi tsyvilizatsiyi (translat. from Germ). Kyiv: Libra, $400 \mathrm{p}$.

Koehn, D. (2020). How Would Confucian Virtue Ethics for Business Differ from Aristotelian Virtue Ethics?. J Bus Ethics, 165: 205-219. DOI : https://doi.org/10.1007/s10551-01904303-8.

Kolot, A. M., Hrishnova, O. A., Herasymenko O. O. et al. (2015). Sotsialna vidpovidalnist. Kyiv : KNEU, 519 p. (In Ukrainian)

Kravchenko, A. A. (2013). Arkhetyp uchytelya: ideya, obraz, vidpovidalnist [Archetype of the teacher: idea, image, responsibility: monograph]. Lviv : Vyd-vo "Liha-Pres" (In Ukrainian)

Morsing, M., \& Spence, L. J. (2019). Corporate social responsibility (CSR) communication and small and medium sized enterprises: The governmentality dilemma of explicit and implicit CSR communication. Human Relations, 72(12): 19201947. DOI: https://doi.org/10.1177/0018726718804306.

Platonova, A. V. (2013). Subyekty moralnogo soznaniya v sovremennom obshchestve: o tipakh kollektivnoy otvet- 
stvennosti. Vestnik Tomskogo gosudarstvennogo universiteta. 373: 75-79. (In Russian)

Ruchkina, M. V. (2008). Otvetstvennost kak sposob samozashchity subyekta riska. Izvestiya Rossiyskogo gosudarstvennogo pedagogicheskogo universiteta im. A. I. Gertsena, 82 (1): 309-315. (In Russian)

Shybko, O. I. (2012). Zrostannya sotsialnoyi vidpovidalnosti yak obyektyvna zakonomirnist tsyvilizatsiynoho postupu [The growth of social responsibility as an objective law of civilized progress,] Skhid, 5 (119) : 150-153 (In Ukrainian).
Silveira R.A., Muzzio H., Costa F.J. (2015). A Philosophical Reflection about Ethics and Corporate Social Responsibility. Revista de Negocios, 20 (3). DOl: http://dx.doi.org/10.7867/1980-4431.2015v20n3p16-27

Titarenko, O. (2008). Istoriya rozvytku katehoriyi «vidpovidalnist» u sotsialniy filosofiyi. Humanitarnyy chasopys, 2: 122-130. (In Ukrainian)

Yermolenko, A. N. (1994). Etika otvetstvennosti $i$ sotsialnoye bytiye cheloveka. Kyiv: Naukova dumka, 200 p. (In Russian)

Марина Дєліні,

Національний університет біоресурсів та природокористування Украӥни (м. Київ, Украӥна)

e-mail: marina.dielini@gmail.com,ORCID0000-0003-1016-2305

\section{ЕВОЛЮЦІЯ БІЗНЕС-ЕТИКИ: ВІД ЗАГАЛЬНОФІЛОСОФСЬКИХ ПРИНЦИПІВ ДО КОРПОРАТИВНОЇ СОЦІАЛЬНОЇ ВІДПОВІДАЛЬНОСТІ}

У статті простежено еволюцію бізнес-етики від висунутих античними мислителями ідей простої відповідальності людини до складних філософських морально-етичних, соціально-економічних побудов щодо корпоративної соціальної відповідальності. Зазначено, що в процесі такої еволюції сформувалася ціла система поглядів, суджень та конструкцій, які слід розглядати як своєрідні етапи подальшого теоретичного осмислення та розширення тематичних рамок феномену «корпоративна соціальна відповідальність». Проведений аналіз показав, що питання бізнес-етики та соціальної відповідальності (і корпоративної соціальної відповідальності як найвищого на сьогодні її прояву) завжди найбільше порушувалися у т.зв. переломні моменти зміни світоглядної парадигми людської цивілізації, а найбільш вагомі теоретичні здобутки пов'язані з раціоналізацією соціальних відносин, коли набуті морально-духовні цінності включалися в процес прирощення соціально-економічних ресурсів суспільства. Показано, що в XXI столітті з боку бізнесу спостерігається стійкий запит на вивчення проблематики соціальної відповідальності, що дає змогу соціальним технологам - представникам різних наукових напрямів розширювати категоріальний апарат, наповнюючи новим змістом базові поняття бізнесетики, а також ініціювати нові наукові дискусії щодо співвідношення морально-ціннісних засад суспільства та різного роду прагматичних концепцій, складниками яких є «принципи-процес-результати».

Ключові слова: відповідальність; соціальна відповідальність бізнесу; етика; мораль; особистісна відповідальність.

(C) Maryna Dielini

Надійшла до редакції: 21.08.2020

Прийнята до друку: 07.10.2020 